\title{
Film Dokumenter Tari Kecak Bedulu “Terkikisnya Eksistensi Di Tanah Kelahirannya"
}

\author{
Ida Bagus Rahadi Ekaputra ${ }^{1}$, I Gede Partha Sindu², P Wayan Arta Suyasa ${ }^{3}$ \\ Program Studi Pendidikan Teknik Informatika \\ Jurusan Teknik Informatika \\ Fakultas Teknik dan Kejuruan \\ Universitas Pendidikan Ganesha \\ Email : rahadi944@gmail.com ${ }^{1}$, partha.sindu@ undiksha.ac.id ${ }^{2}$, arta.suyasa@undiksha.ac.id ${ }^{3}$
}

\begin{abstract}
Abstrak- Tari Kecak Bedulu yang juga disebut Tari Cak Bedulu, menjadi tarian perintis lahirnya tari touristik. Lahirnya tarian kecak ini memang sengaja diubah mengingat tingginya minat wisatawan saat itu akan pementasan seni tradisional. Industri pariwisata yang baru tumbuh belum mendapat perhatian pemerintahan kolonial. Film dokumenter dapat menjadi media untuk memberikan informasi sejarah Tari Kecak Bedulu. Penelitian ini bertujuan untuk (1) menghasilkan rancangan dan mengimplementasikan hasil rancangan Film Dokumenter Tari Kecak Bedulu (2) mengetahui respon masyarakat terhadap hasil akhir Film Dokumenter Tari Kecak Bedulu. Jenis penelitian yang digunakan dalam penelitian ini adalah penelitian dan pengembangan dengan model cyclic strategy. Film dokumenter ini diimplementasikan dengan menggunakan aplikasi Adobe Premiere CC 2017 dalam proses video editing, serta Adobe Photoshop CC 2017 untuk pembuatan desain keperluan film dokumenter.
\end{abstract}

Kata Kunci : Tari Kecak Bedulu, Desa Bedulu, Film Dokumenter, Cyclic Strategy.

Abstract-Kecak Bedulu Dance, also called Cak Bedulu Dance, is a pioneer dance for the birth of touristic dance. The birth of the Kecak dance was deliberately changed considering the interest of tourists at that time would be the performance of traditional arts. The newly growing tourism industry has not received the attention of the colonial government. Documentary films can be a medium for providing historical information on Bedulu Kecak Dance. This study aims to (1) produce and implement the results of the design of the Bedulu Kecak Dance Documentary Film (2) Find the public response to the final results of the Bedulu Kecak Dance Documentary Film. The type of research used in this study is research and development with a cycle strategy model. This documentary is implemented using the Adobe Premiere CC2017 application in the process of editing videos, and Adobe Photoshop CC 2017 for making documentary design needs.
Keywords: Kecak Bedulu Dance, Bedulu Village, Film Documentary, Cyclic Strategy

\section{PENDAHULUAN}

Bali salah satu daerah di Indonesia yang memiliki bermacam - macam kesenian. Setiap daerah di Bali pasti memiliki kesenian dengan keunikannya masing - masing. Kesenian yang dimaksud yakni, seni tari tradional yang tumbuh dan berkembang hingg saat ini. Adapun jenis- jenis seni tari, diantaranya tari barong, tari lengong, tari pendet dan tari kecak. Bedulu merupakan sebuah desa di kabupaten Gianyar, dimana di desa ini masih mementaskan dan melestarikan salah satu jenis tari yang dimaksud, yaitu seni tari kecak.

Tari Kecak Bedulu yang juga disebut Tari Cak Bedulu, menjadi tarian perintis lahirnya tari touristik. Ketika diciptakan di desa pakraman Bedulu di tahun 1930-an, Bali mulai didatangi wisatawan asal Eropa. Terutama dari negeri Belanda yang memegang kendali kekuasaan dalam pemerintahan kolonial di tanah nusantara ketika itu. Sulitnya menyaksikan prosesi ritual keagamaan maupun atraksi budaya tradisonal, menggugah kreatifitas serta menjadi pemikiran seorang seniman bernama Walter Spiese[1].

Lahirnya tari kecak ini memang sengaja diubah mengingat tingginya minat wisatawan saat itu akan pementasan seni tradisional. Industri pariwisata yang baru tumbuh belum mendapat perhatian pemerintahan kolonial. Seorang seniman Walter Spiese yang tergerak hatinya untuk mengembangkan jiwa berkesenian masyarakat Bedulu. Tidak berhenti dalan menggugah, Walter Spiese juga sempat memperkenalkan tari kecak ini ke sejumlah wisatawan dan mementaskan tarian ini di berbagai negeri. Wisatawan asing mulai berdatangan, berbagai usaha yang berkaitan dengan aktifitas kepariwisataan juga bermunculan[1].

Seiring perkembangan zaman dan era digital, seni tari kecak bedulu kini berangsur-angsur semakin dilupakan khusunya generasi muda masyarakat bedulu. Hal ini dibuktikan berdasarkan hasil wawancara yang dilakukan 13 November 2017 dengan I Made Rinto Waguandes selaku yang melestarikan dari Kecak Bedulu menjelaskan bahwa kurangnya yang mengetahui tentang Sejarah Tari Kecak Bedulu dan mulai di lupakannya Tari Kecak Bedulu tersebut. Pengaruh generasi 


\section{ISSN \\ Kumpulan Artikel Mahasiswa Pendidikan Teknik Informatika}

(KARMAPATI)

muda ini memiliki dampak kelangsungan dan berpengaruh pada popularitas dari kecak bedulu dimasa selanjutnya. Beliau juga menambahkan keunikan lainnya juga Kecak Bedulu ini menampilkan penggalan - penggalan cerita saja dari Kecak lainnya. Tari Kecak Bedulu ini juga menggunakan riasan yang sederhana pada pemeran adegan cerita yang di tampilkan pada kecak tersebut, jika biasanya pemeran menggunankan riasan yang megah dan mewah lain halnya dengan Tari Kecak Bedulu[1]

Berdasarkan hasil respon dari masyarakat setempat dari penyebaran angket, sejumlah $90 \%$ masyarakat mengetahui atau pernah mendengar Tari Kecak Bedulu. Hanya sejumlah $25 \%$ masyarakat mengetahui dan $75 \%$ masayarakat yang tidak mengetahui sejarah Tari Kecak Bedulu. Sebanyak 35\% masyarakat yang pernah melihat dan $65 \%$ masyarakat yang tidak pernah melihat berupa media yang memberikan informasi tentang Tari Kecak Bedulu. Berdasarkan hasil penyebaran angket secara umum masyarakat sangat ingin mengetahui Tari Kecak Bedulu. Sebanyak 100\% masyarakat sangat tertarik menonton suatu film dokumenter yang memberikan informasi tentang Tari Kecak Bedulu. Melihat hal tersebut, maka dirasa perlu untuk mengenalkan kembali salah satu warisan budaya Desa Bedulu kepada masyarakat dan para generasi muda sekaligus menaikkan keeksistensiannya lewat salah satu media komunikasi, yaitu film dengan teknik dokumentasi atau lebih dikenal dengan nama film documenter.

Melihat hal tersebut, untuk mengatasi masalah regnerasi terkait tari kecak penulis bermakud membuat sebuah karya film dengan memanfaatkan teknologi yang berkembang saat ini, misalnya editing, dan lain-lain. Sebagai solusi permasalahan berdasarkan uraian diatas, penulis tertarik untuk membuat sebuah film documenter

Penelitian terkait pembuatan film dokumenter sudah pernah dilakukan sebelumnya oleh peneliti lain. Contoh penelitian tersebut yaitu Film Dokumenter PTI : Rumahku (Sebuah Catatan, Sebuah Kisah) di buat oleh I Gusti Ngurah Agung Pramasurya Dwi Septian, Gede Saindra Santyadiputra, dan I Made Agus Wirawan, (2017). Film Dokumenter ini bertujuan mengetahui sejarah berdirinya jurusan Pendidikan Teknik Informatika Undiksha.

Berdasarkan uraian di atas, peneliti merasa sangat perlu untuk membuat sebuah media film dokumenter yang diperuntukan untuk memperkenalkan dan melestarikan Tari Kecak Bedulu dengan judul Film Dokumenter Tari Kecak Bedulu "Terkikisnya Eksistensi DiTanah Kelahirannya" sebagai media untuk memperkenalkan, melestarikan, serta sebagai media dokumentasi.

Hasil akhir yang akan berbentuk film dokumenter tentang Tari Kecak Bedului ini akan memberikan beberapa manfaat yaitu sebagai berikut:

1. Manfaat Teoritis

a. Bagi peneliti

Peneliti sebagai pihak pembuat film dokumenter akan mendapatkan wawasan baru tentang sejarah dan kekayaan budaya. Selain itu pembuatan film akan menjadi ajang mengasah keterampilan yang didapat saat kuliah untuk diaplikasikan secara nyata.
Volume 8, Nomor 2, Tahun 2019

2. Manfaat Praktis

a. Bagi masyarakat

Masyarakat umum akan mengetahui Tari Kecak Bedulu dan khususnya untuk generasi muda yang tinggal di Desa Bedulu menyadari pentingnya eksistensi kebudayaan lokal yang dimiliki sebagai warisan peradaban di masa lampau untuk dilestarikan sebagai penjunjung nilai sejarah yang sangat penuh akan nilai sejarah, filosofis, dan keunikan budaya. Selain itu juga bermanfaat untuk masyarakat umum dalam menambah wawasan akan keanekaragaman bentuk budaya nusantara.

b. Bagi sejarawan

Sejarawan akan mendapatkan bentuk baru penyebaran informasi sejarah selain dalam bentuk buku/tulisan, yaitu sebuah bentuk film dokumentar.

c. Bagi pelaku documenter

Pelaku dokumenter lain akan mendapatkan pembanding atau acuan, baik bagi yang sudah maupun baru memulai praktek dokumenter.

\section{KAJIAN TEORI}

\section{A. Tari Kecak Bedulu}

Tari Kecak Bedulu yang juga disebut Tari Cak Bedulu, menjadi tarian perintis lahirnya tari touristik. Ketika dicipta di desa pakraman Bedulu di tahun 1930-an, Bali mulai didatangi wisatawan asal Eropa. Terutama dari negeri Belanda yang memegang kendali kekuasaan dalam pemerintahan kolonial di tanah nusantara ketika itu[1].

Sulitnya menyaksikan prosesi ritual keagamaan maupun atraksi budaya tradisonal, menggugah kreatifitas serta menjadi pemikiran seorang seniman bernama Walter Spiese. Pesenise yang juga seorang koreografer kenamaan asal Belanda ini, pernah menetap di desa pakraman Bedulu. Di desa yang yang pernah menjadi pusat kerajaan besar yang menguasai bumi Bali dan sekitarnya ini, Walter Spiese berkenalan dengan berbagai seni dan budaya lokal. Termasuk tari sang hyang jaran yang sangat disakralkan oleh warga setempat. Keunikan tari yang menari di atas bara api diiringi nyanyian khas sang hyang jaran, menggugah naluri berkesenian seorang Walter Spiese. Dalam kelompok penyanyi yang mengirini pementasan tari sang hyang jaran ini, dilantunkan tembang sekar alit, seperti instrimentalia dalam tarian kecak seperti saat ini[1].

Dengan menjalin komunikasi serta berkonsultasi dengan seniman asal Bedulu yang tumbuh subur saat itu, Walter Spiese akhirnya mencetuskan tari kreasi yang disebut tari cak atau kecak. Dengan memasukan unsur berkesenian yang dipadu dengan koreografi barat, Walter Spiese menyebut tari gubahannya bersama seniman dan tokoh desa setempat dengan tari cak. Dalam tahap konsultasi ini Walter Spirse menolak pementasan tarian sang hyang jaran untuk menghibur wisatawan asing yang muli berdatangan. Penolakan seorang Walter Spiese ini sebagai rasa hormat dan penghargaan terhadap unsur seni tradisional. Kondisi Sangat berbeda sengan 


\section{Kumpulan Artikel Mahasiswa Pendidikan Teknik Informatika}

kenyataan dalam kekinian tokoh dan para pelaku seni yang ada. Hanya demi kepentingan subjektif yang dilandasi materi atau jabatan, tidak sedikit seni tradisi sakral justru dinistakan. Pantangan yang senantiasa menjadi pegangan dalam kehidupan spiritual keagamaan justru diobral dengan membuka ruang penistaan.

\section{B. Film Dokumenter}

Undang undang Republik Indonesia Nomor 8 Tahun 1992 tentang Perfilman Bab 1 Pasal 1 Film adalah karya cipta seni dan budaya yang dibuat berdasarkan asas sinematografi dengan direkam pada pita seluloid, pita video, piringan video, dan/atau bahan atau hasil penemuan teknologi lainnya dalam segala bentuk, jenis dan ukuran melalui proses kimiawi, proses elektronik, atau proses lainnya, dengan atau tanpa suara, yang dapat dipertunjukkan dan/atau ditayangkan dengan sistem proyeksi mekanik, elektronik, dan/atau penayangan film [2].

Dokumenter adalah sebutan yang diberikan untuk film pertama karya Lumiere bersaudara yang berkisah tentang perjalanan (travelogues) yang dibuat sekitar tahun 1890-an. Tiga puluh enam tahun kemudian, kata 'dokumenter' kembali digunakan oleh pembuat film dan kritikus film asal Inggris John Grierson untuk film Moana (1926) karya Robert Flaherty. Grierson berpendapat dokumenter merupakan suatu bentuk informasi, propaganda, edukasi, dan cara kreatif untuk merepresentasikan realita [3].

Dalam program dokumenter terkandung unsur nilai dan faktual .Dalam hal ini faktual berarti nyata, ada dan pernah terjadi. Nilai adalah esensial dan bermakna. Dokumenter adalah dokumen dalam hal ini bisa berupa tulisan, catatan, gambar, film, foto, video dari sebuah peristiwa masa lampau yang memiliki makna bagi suatu lingkungan/daerah, sehingga yang dapat mengetahui dokumen ini adalah sebuah dokumenter adalah lingkungan itu sendiri (Sartono, 2008) [4].

Film dokumenter dibagi menjadi delapan jenis. Jenis-jenis film dokumeter, antara lain :

1. Laporan Perjalanan.

2. Sejarah.

3. Biografi :

a) Potret.

b) Biografi.

c) Profil.

4. Nostalgia.

5. Rekonstruksi.

6. Investigasi.

7. Perbandingan dan Kontradiksi.

8. Ilmu Pengetahuan.

9. Buku Harian.

10. Association Picture Story.

11. Dokudrama.

12. Eksperimen Seni.
Volume 8, Nomor 2, Tahun 2019

\section{Model Cyclic Strategy}

Model penelitian yang digunakan untuk Film Dokumenter Tari Kecak "Terkikisnya Eksistensi Ditanah Kelahirannya" adalah model cyclic strategy. Model cyclic strategy atau startegi berputar merupakan sebuah metode yang ada kalanya suatu tahap perlu diulang kembali sebelum tahap berikutnya dilanjutkan. Pengulangan tahap ini sering disebut dengan loop. Pengulangan tahap ini dimaksudkan untuk menampung umpan balik (feed back) sebelum tahap berikutnya dilanjutkan [5]. Tahap - tahap yang ada pada model cyclic strategy dapat dilihat pada Gambar 1 .

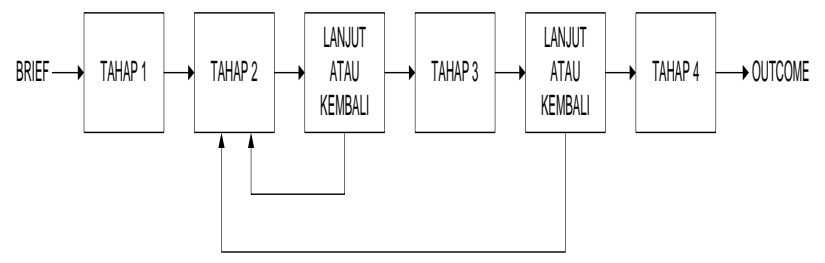

Gambar 1.

Model Cyclic Strategy

\section{METODOLOGI PENELITIAN}

\section{A. Metode Penelitian}

Metode penelitian yang digunakan untuk film dokumenter Tari Kecak Bedulu "Terkikisnya Eksistensi Ditanah Kelahirannya" adalah model cyclic strategy atau strategi berputar. Tahap-tahap dalam model cyclic strategy yang diimplementasikan ke dalam metodologi penelitian dapat dilihat pada Gambar 2.

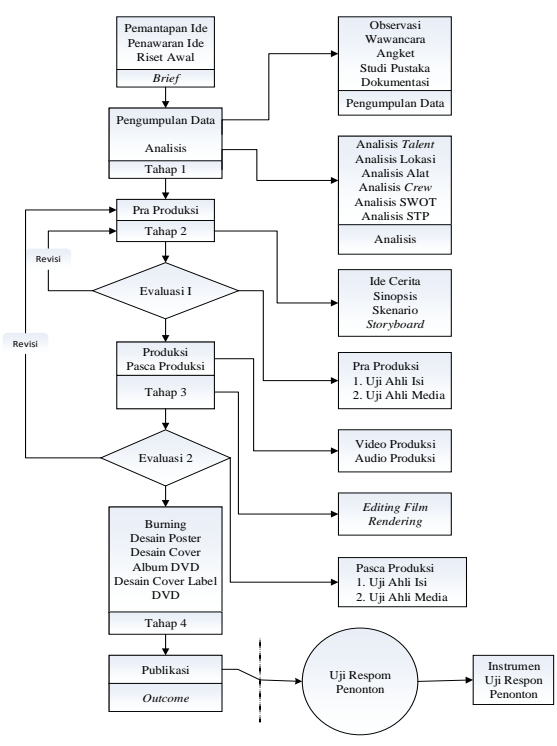

Gambar 2 Tahapan

Metode Cyclic Strategy 
1) Brief (Pemantapan Ide, Penawaran Ide,Riset Awal)

Brief merupakan tahap awal dari perancangan Film Dokumenter Tari Kecak "Terkikisnya Eksistensi Ditanah Kelahirannya". Pada tahapan ini terdapat tiga fase yaitu :

1. pemantapan ide.

2. penawaran ide.

3. riset awal.

2) Tahap 1 (Permasalahan, Pengumpulan Data, dan Analisis)

1. Permasalahan.

Pada fase ini penulis menemukan permasalahan yang akan dirancang menjadi sebuah film dokumenter.

2. Pengumpulan Data

Teknik pengumpulan data tersebut dijabarkan sebagai berikut.:

a. Observasi.

b. Wawancara.

c. Penyebaran angket kuesioner.

d. Studi pustaka.

e. Dokumentasi.

3. Analisis

Setelah data terkumpul, maka dilakukan sebuah analisis guna mengetahui kelebihan, kekurangan maupun target audiens film dokumenter. Berikut merupakan analisis yang dibutuhkan dalam pebutan film dokumenter :

a. Analisa Talent

b. Analisa Lokasi

c. Analisa Alat

d. Analisa Crew

e. Analisa SWOT

f. Analisa STP.

\section{3) Tahap 2 ( Pra Produksi )}

Pada tahap 2 terdapat fase pra produksi. Di mana fase pra produksi sangat menentukan dalam sukses atau tidaknya sebuah film. Informasi yang telah terkumpul pada fase pengumpulan data akan diolah di fase pra produksi. Data yang telah terkumpul akan menjadi gambaran untuk merancang sebuah konsep karya film. Dalam tahap ini, konsep akan direalisasikan. Pra produksi meliputi beberapa tahapan, yaitu perancangan ide cerita (konsep), perancangan sinopsis, perancangan skenario, dan perancangan storyboard.

4) Evaluasi 1

Setelah tahap 2 ini akan ada pengujian yang bertujuan mengecek kembali apakah semua bagian dalam tahap 1 dan tahap 2 telah benar-benar terlaksana. Jika ada yang belum terlaksana maka akan dilakukan looping / pengulangan dengan
Volume 8, Nomor 2, Tahun 2019 merevisi kembali rancangan film. Sedangkan jika semua telah terlaksana maka akan dilajutkan ke tahap berikutnya. Pengujian di sini dilakukan oleh peneliti itu sendiri.

5) Tahap 3 ( Produksi dan Pasca Produksi )

Adapun fase-fase yang terdapat pada Tahap 3 yaitu :

1. Produksi

Pada fase ini dibagi menjadi dua, antara lain:
a. Video Production
b. Audio Production

2. Pasca Produksi

Dalam tahapan pasca produksi dilakukan beberapa hal, antara lain:
a. Video Editing
b. Sound Editing
c. Rendering
d. Review Editing

6) Evaluasi 2 ( Evaluasi Ahli )

Setelah Tahap 3 selesai, maka film dokumenter tersebut dievaluasi oleh para ahli di Tahap Evaluasi 2. Terdapat da pengujian, yaitu uji ahli isi dan uji ahli media.

\section{7) Tahap 4}

Tahap 4 merupakan tahapan akhir sebelum film ini disebarluaskan. Pada tahap 4 ini terdapat fase mastering. Mastering merupakan proses dimana file yang telah di-render dipindahkan kedalam media DVD atau media lainya. Pada tahap ini juga dilakukan perancangan desain cover. Berikut design cover DVD dan sampul DVD.

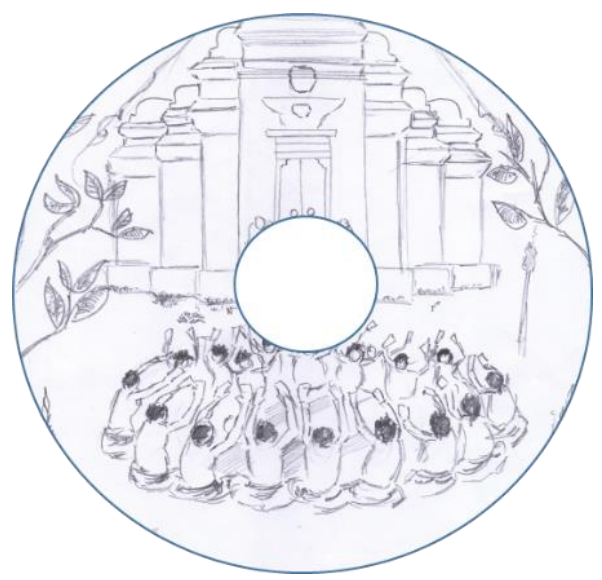

Gambar 3. Design Cover DVD 


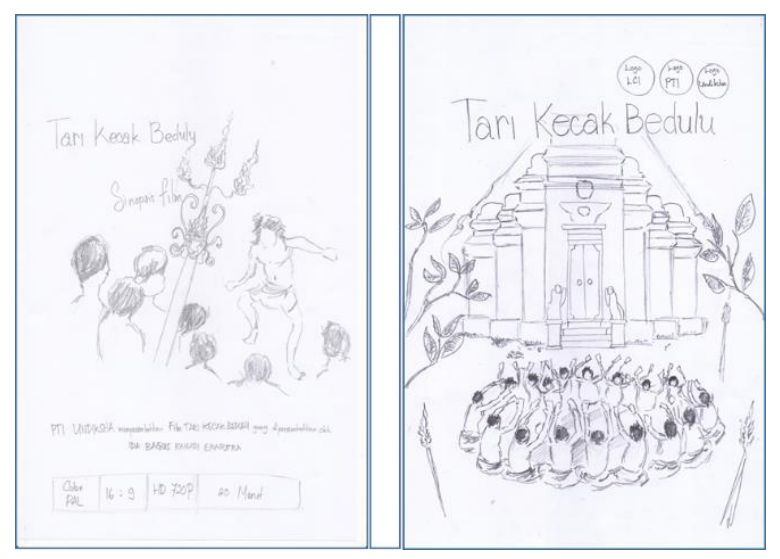

Gambar 4.

Design Sampul DVD

\section{8) Outcome}

Outcome merupakan tahapan terakhir dari pembuatan film dokumenter ini. Tahap terakhir yaitu publikasi. Produk akhir film yang telah dikemas dalam bentuk DVD siap dipublikasikan, target publikasi disesuaikan dengan target penonton. Pada tahap ini juga dilakukan promosi yaitu dengan cara membuat poster dan trailer film. Tahap ini juga dilakukan uji respon dengan tujuan untuk mengetahui respon penonton tentang film dokumenter.

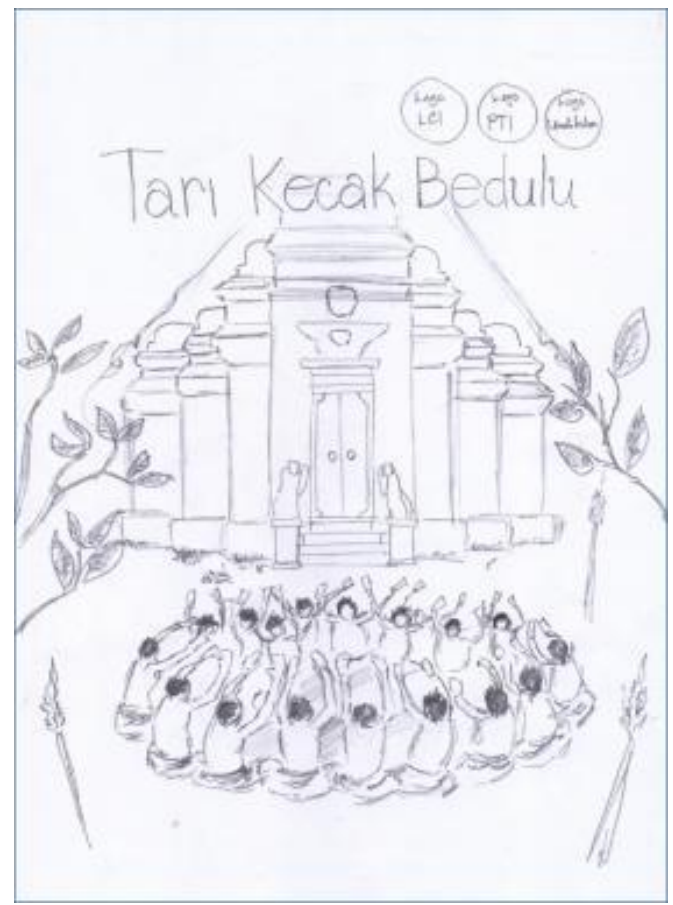

Gambar 5.

Design Poster
Volume 8, Nomor 2, Tahun 2019

\section{HASIL \& PEMBAHASAN}

\section{A. Hasil Tahap Brief}

Brief merupakan tahap persiapan awal untul melakukan penelitian ini. Di mana tahap awal dari Tari Kecak Bedulu "Terkikisnya Eksistensi Ditanah Kelahirannya" yaitu pemantapan ide dan penawaran ide/topik terhadap Jurusan Teknik Informatika. Ide/topik tersebut diajukan dan disetujui pada tanggal 27 Oktober 2017. Kemudian dilakukan riset awal terkait permasalah yang terjadi pada Tari Kecak Bedulu yang ada di Desa Bedulu, Kabupaten Gianyar.

B. Hasil Tahap 1 (Pengumpulan data \& Analisis)

Pada tahap 1 ini terdapat beberapa fase yaitu pengumpulan data dan analisis. Di mana hasil dari fase tersebut dapat dijabarkan sebagai berikut.

1. Pengumpulan data

Dalam pembuatan film dokumenter ini menggunakan beberapa teknik pengumpulan data. Teknik pengumpulan data dijabarkan sebagai berikut.

a. Observasi.

Pengumpulan data melalui observasi dilaksanakan dengan cara datang langsung ke Desa Bedulu untuk melihat situasi desa dan kegiatan perkumpulan Sekaa Kecak yang berada di Desa Bedulu.

b. Wawancara

Melakukan wawancara dengan narasumber yang berkompeten mengenai Tari Kecak Bedulu. Wawancara dilakukan dengan beberapa narasumber sebagai berikut:

1. Putu Ariawan, (Selaku Tokoh Masyarakat dan Ketua Sekaa Kecak Bedulu)

2. I Made Rinto Waguandes, S.Sn ( Selaku Wakil Ketua Sekaa Kecak Bedulu dan Praktisi Tari Kecak Bedulu)

Wawancara ini membahas terkait Sejarah dan Perkembangan Tari Kecak Bedulu guna mendapatkan data-data mengenai Tari Kecak Bedulu yang digunakan dalam penelitian ini. Dalam wawancara ini juga dijadikan sebagai acuan untuk menentukan narasumber utama dalam Film Dokumenter Tari Kecak Bedulu "Terkikisnya Eksistensi Di Tanah Kelahirannya”.

c.Penyebaran Angket Kuesioner

Penyebaran angket kuesioner dilakukan guna mendapatkan data-data awal dari masyarakat umum 
Volume 8, Nomor 2, Tahun 2019

utamanya generasi muda tentang pengetahuannya terhadap Tari Kecak Bedulu. Hasil angket awal dapat dilihat pada Lampiran 3. Sedangkan rekapitulasi angket awal tersebut dapat di lihat pada Lampiran 4. Hasil dari angket kuisioner ini digunakan untuk memperkuat latar belakang penelitian. Total keseluruhan responden adalah 30 orang.

d. Studi Pustaka

Studi pustaka dilakukan untuk mengumpulkan sumber tertulis maupun tidak tertulis seperti buku, jurnal, internet, majalah, koran, dan artikel terkait, baik yang dipublikasikan mau pun non publikasi.

e. Dokumentasi

Dokumentasi dilakukan secara terjadwal untuk wawancara dengan narasumber sedangkan dokumentasi selain itu dilakukan secara acak.

\section{Analisis}

Hasil dari fase pengumpulan data tersebut dianalisa di fase analisis guna mengetahui kebutuhan film, kelebihan, kekurangan maupun target penonton. Hasil yang dilakukan fase analisis ini diantaranya sebagai berikut :

a. Penentuan talent

Adapun talent yang terlibat dalam Film Dokumenter Tari Kecak Bedulu "Terkikisnya Eksistensi Di Tanah Kelahirannya" yaitu:

1) Narasumber

Narasumber dipilih dengan pertimbangan dan tujuan yang relevan dengan arah dokumentasi. Adapun narasumber dalam dalam Film Dokumenter Tari Kecak Bedulu "Terkikisnya Eksistensi Di Tanah Kelahirannya" yaitu:

1. Putu Ariawan, (Selaku Tokoh Masyarakat dan Ketua Sekaa Kecak Bedulu)

2. I Made Rinto Waguandes, S.Sn ( Selaku Wakil Ketua Sekaa Kecak Bedulu dan Praktisi Tari Kecak Bedulu)

2) Pementasan Tari Kecak Bedulu: Perkumpulan Anggota Sekaa Kecak Bedulu.

3) Pelatihan Tari Kecak Bedulu :

a) Pembina: Putu Ariawan, (Selaku Tokoh Masyarakat dan Ketua Sekaa Kecak Bedulu)

b) Peserta: Anggota Sekaa Kecak Bedulu.

b. Penentuan lokasi

Lokasi shooting pembuatan Film Dokumenter Tari Kecak Bedulu "Terkikisnya Eksistensi Di Tanah Kelahirannya" ini lebih banyak menggunakan lokasi shooting outdoor. Lokasi shooting berpusat di Desa Bedulu, Kecamatan Blahbatuh, Kabupaten Gianyar karena fokus film ini untuk mengangkat Tarik Kecak yang ada di Desa bedulu. Adapun tempat lokasi Shooting Film Dokumenter Tari Kecak Bedulu "Terkikisnya Eksistensi Di Tanah Kelahirannya" yaitu:

1. Pura Samuan Tiga (Outdoor).

2. Rumah kediaman narasumber 1. Putu Ariawan (Indoor).

3. Daerah Persawahan Desa Bedulu (Outdoor).

4. Tempat Wisata Goa Gajah dan Yeh Pulu (Outdoor).

5. Desa Bedulu (Outdoor).

6. Rumah kediaman narasumber 2. I Made Rinto Waguandes, S.Sn (Indoor).

c. Penentuan Peralatan alat

Adapun peralatan yang digunakan dalam pembuatan Film Dokumenter Tari Kecak Bedulu "Terkikisnya Eksistensi Di Tanah Kelahirannya" yaitu:

1. Kamera DSLR Canon 60 D.

2. Kamera DSLR Canon 700 D.

3. Kamera DSLR Canon 1200 D.

4. Kamera Mirrorless Sony a6500.

5. Drone Dji Spark

6. Tripod.

7. Takstar microphone.

8. Komputer. Dengan spesifikasi sebagai berikut:

a) Proccesor Intel(R) Core(TM) i7.

b) Memory (RAM) 8GB DDR5.

c) Harddisk 1TB.

d) Nvidia GTX 1050 (4GB)

e) DVD/RW

d. Penentuan Crew

Crew film sangat dibutuhkan dalam membantu proses produksi yaitu pada saat shooting. Adapun crew film dalam pembuatan Film Dokumenter Tari Kecak Bedulu "Terkikisnya Eksistensi Di Tanah Kelahirannya" yaitu:

1. Produser : Ida Bagus Rahadi Ekaputra.

2. Penulis Skenario : Ida Bagus Rahadi Ekaputra.

3. Sutradara : Ida Bagus Rahadi Ekaputra.

4. Cameraman 1 : Ida Bagus Rahadi Ekaputra.

5. Cameraman 2 : Pande Komang Saputra.

6. Cameraman 3 :Puta Arya Peringgayudha. 
7. Editor : Ida Bagus Rahadi Ekaputra.

8. Drone Pilot : Ida Bagus Rahadi Ekaputra.

9. Narator : Eva Roosyana Dewi

e. SWOT (Strenght, Weakness, Opportunity, Treat)

Analisis SWOT dilakukan untuk mengetahui kekuatan, kelemahan, kesempatan yang bisa didapat, serta ancaman yang mungkin terjadi pada film tersebut. Hal inilah yang akan digunakan sebagai tolak ukur, antara SWOT pada Film Dokumenter Tari Kecak Bedulu "Terkikisnya Eksistensi Di Tanah Kelahirannya" dan film referensi. Analisis SWOT pada Film Dokumenter Tari Kecak Bedulu "Terkikisnya Eksistensi Di Tanah Kelahirannya" adalah sebagai berikut.

1. Strength (Kekuatan)

a) Kekuatan film ini terletak pada ide cerita yang diangkat merupakan sebuah tari kecak bedulu yang menceritakan tentang sejarah dan perkembangan tari kecak tersebut.

b) Kekuatan film juga terletak pada keunikan dari kecak bedulu tersebut.

2. Weakness (Kelemahan)

a) Keterbatasan alat yang digunakan dalam pembuatan film dokumenter ini yang akan menyebabkan teknik pengambilan gambar yang kurang sempurna.

b) Keterbatasan biaya produksi.

c) Jumlah crew yang terbatas dan masih amatiran.

3. Opportunity (Peluang)

a) Informasi yang disajikan bersifat mengajak penonton dan memberikan tontonan mengenai tari kecak bedulu.

b) Peluang film ini untuk ditonton oleh khalayak banyak cukup besar karena kisah yang diceritakan belum pernah diangkat dalam film dokumenter.

4. Threat (Ancaman)

a) Jadwal pertunjukan kecak jarang dapat dijumpai sehingga susah untuk menentukan jadwal pengambilan video.

b) Selain itu, karena kebanyakan pengambilan gambar dilakukan di luar ruangan (outdoor), maka banyak faktor yang akan mengganggu dalam pengambilan gambar seperti hujan, kebisingan suara, dan lain-lain.

f. STP (Segmentating, Targeting, Positioning)

Analisa STP yang terdiri dari beberapa kriteria berupa pemilahan (segmentating), tujuan/target (targeting), dan penempatan (positioning). Analisis STP pada Film Dokumenter Tari Kecak Bedulu "Terkikisnya Eksistensi Di Tanah Kelahirannya" adalah sebagai berikut.

1. Segmentating

a) Geografis

Ditujukkan untuk semua wilayah yang ada di Indonesia serta nantinya akan disertakan subtitle berbahasa inggris agar segementasi target pemasaran bisa mencapai luar negeri.

b) Demografis

Film ini dapat ditonton oleh usia 8 s.d 60 tahun serta penonton mencangkup kaum lakilaki maupun perempuan dengan segala jenis pekerjaan tanpa ada batasan.

c) Psikografis

Dapat disaksikan oleh segala lapisan sosial.

\section{2. $\quad$ Targeting}

Target utama penyebaran film adalah badan / organisasi / komunitas yang memiliki tujuan untuk melestarikan kebudayaan yang ada di Bali. Dengan begitu baik target utama maupun penulis akan saling terbantu, di mana target utama akan mendapatkan sebuah media audio visual untuk melakukan sosialisasi terkait Tari Kecak Bedulu dan upaya pelestariannya begitu pula dengan penulis, akan terbantu dalam penyebarluasan film ini ke target yang lebih umum yaitu masyarakat luas. Di mana target umum tidak dibatasi, hanya berpatok pada usia yang berada di kisaran 8 s.d 60 tahun.

\section{Positioning}

Film ini akan menjadi film pertama yang mengangkat Sejarah dan Perkembangan Tari Kecak Bedulu di Desa Bedulu yang merupakan Tari Kecak yang memiliki banyak keunikan selain itu film ini juga akan mengajak penonton untuk peduli dan ikut melestarikan Tari Kecak tersebut. 


\section{ISSN \\ Kumpulan Artikel Mahasiswa Pendidikan Teknik Informatika}

(KARMAPATI)

3. Hasil Tahap 2 (Ide, Sinopsis, Skenario, Storyboard)

Pada tahap ini terdapat fase pra produksi. Dalam tahap ini, konsep direalisasikan dalam bentuk sinopsis sebelum dituangkan ke dalam bentuk ide/konsep film, sinopsis, skenario, dan storyboard. Adapaun Hasil dilakukan pada tahapan ini antara lain

1) Ide/Konsep Film

Ide cerita merupakan bagian dasar untuk pembuatan sebuah film dokumenter. Ide cerita dari pembuatan Film Dokumenter Tari Kecak Bedulu "Terkikisnya Eksistensi Di Tanah Kelahirannya" dibuat berdasarkan cerita fakta hasil observasi dan wawancara denganI Made Rinto Waguandes, S.Sn (Gianyar) Selaku Wakil Ketua Sekaa Kecak Bedulu dan Praktisi Tari Kecak Bedulu. Di mana dalam hasil observasi dan wawancara tersebut ditemukan fakta bahwa kurangnya minat generasi muda untuk ikut berperan dalam pelestarian Tari Kecak Bedulu. Film Dokumenter Tari Kecak Bedulu "Terkikisnya Eksistensi Di Tanah Kelahirannya" ini diceritakan tentang sejarah drama Tari Kecak Bedulu, keunikan Tari Kecak Bedulu dan perkembangan drama Tari Kecak bedulu hingga sekarang dengan tujuan memperkenalkannya kepada masyarakat dengan harapan agar masyarakat khususnya generasi muda memiliki minat unutk mempelajarinya atau setidaknya mau ikut melestarikan Tari Kecak Bedulu.

2) Sinopsis

Adapun sinopsis dari Film Dokumenter Tari Kecak Bedulu "Terkikisnya Eksistensi Di Tanah Kelahirannya" sebagai berikut.

Tari Kecak Bedulu merupakan tarian perintis lahirnya tari untuk wistawan. Tari Kecak Bedulu diciptakan di desa pakraman Bedulu di tahun 1930-an, Bali mulai didatangi wisatawan asal Eropa. Sulitnya menyaksikan prosesi ritual keagamaan maupun atraksi budaya tradisonal, menggugah kreatifitas serta menjadi pemikiran seorang seniman bernama Walter Spiese untuk membuat sebuah tarian yang bisa dipertontonkan ke publik secara bebas.

Film dokumenter Tari Kecak Bedulu ini menceritakan Tari kecak Bedulu tepatnya di Desa Bedulu, Kecamatan Blahbatuh, Kabupaten Gianyar yang memiliki keunikan dimana tari kecak tersebut tidak menampilkan seluruh cerita tapi hanya penggalan - penggalan cerita. Tari Kecak Bedulu ini dibuat untuk memanjakan wisatawan agar dapat menyaksikan Tari Kecak tersebut. Umumnya Tari Kecak biasanya adalah tarian yang sakral yang biasa ditampilkan pada upacara keagamaan dan tidak bebas untuk di pentaskan. Seiring perkembangan zaman eksistensi Tari
Volume 8, Nomor 2, Tahun 2019

Kecak Bedulu semakin menurun akibat kurangnya regenerasi.

Film dokumenter ini menjelaskan sejarah, keunikan dan menurunnya minat generasi muda untuk melestarikan Tari Kecak Bedulu. Film ini juga akan menjelaskan tentang perkembangan Tari Kecak Bedulu yang masih ada sampai saat ini. Akhir cerita film dokumenter ini akan menyampaikan harapan terhadap film ini dari masyarakat Desa Bedulu.

3) Skenario

Skenario film dokumenter adalah sebuah naskah cerita yang menguraikan urut-urutan adegan, tempat, keadaan, dan dialog, yang disusun dalam konteks struktur dramatik untuk menjadi acuan dalam proses produksi Film Dokumenter Tari Kecak Bedulu "Terkikisnya Eksistensi Di Tanah Kelahirannya".

4) Storyboard

Berdasarkan kronologi yang telah dibangun pada sinopsis dan skenario dibuatlah storyboard sebagai langkah awal alur cerita. Storyboard yang dibangun berupa garis besar tiap prosesi yang ditampilkan dalam film, dalam hal ini berarti rekaman jalannya tiap peristiwa bisa berbeda dengan yang tergambarkan dalam storyboard.

4. Hasil Evaluasi 1

Pada tahap evaluasi 1 ini bertujuan untuk memastikan semua kegiatan yang dilakukan pada proses pra produksi telah terlaksana dengan pemeriksaan checklist.

Tahapan checklist dilakukan oleh peneliti sendiri dengan menulis sesuai hal-hal yang telah dilakukan. Hasil tahapan checklist dapat dilihat pada Tabel 1

Tabel 1 Instrumen checklist

\begin{tabular}{|c|l|c|}
\hline No & \multicolumn{1}{|c|}{ Nama Kegiatan } & Hasil Evaluasi \\
\hline 1 & Perancangan Ide Cerita & Sesuai \\
\hline 2 & Perancangan Sinopsis & Sesuai \\
\hline 3 & Perancangan Skenario & Sesuai \\
\hline 4 & $\begin{array}{l}\text { Perancangan } \\
\text { Storyboard }\end{array}$ & Sesuai \\
\hline 5 & Penentuan Talent & Sesuai \\
\hline 6 & Penentuan Lokasi & Sesuai \\
\hline 7 & Penentuan Peralatan & Sesuai \\
\hline 8 & Penentuan Crew & Sesuai \\
\hline
\end{tabular}

5. Hasil Tahap 3 (Produksi \& Pasca Produksi)

Pada tahap ini terdiri dari fase produksi dan pasca produksi. Berikut hasil dari fase-fase tersebut. 


\section{ISSN \\ Kumpulan Artikel Mahasiswa Pendidikan Teknik Informatika \\ (KARMAPATI)}

\section{1) Produksi}

Hasil pengembilan gambar ini ada beberapa hal yang mungkin berbeda dengan yang ada di storyboard di karenakan storyboard merupakan sebuah perencanaan sedangkan dalam pengambilan gambar sendiri penulis menemukan informasi-informasi baru yang ditemukan di lapangan, namun secara keseluruhan dari segi alur cerita penulis tetap berpatokan pada skenario dan storyboard. Hasil tahapan produksi dapat dilihat pada Gambar 3, Gambar 4.

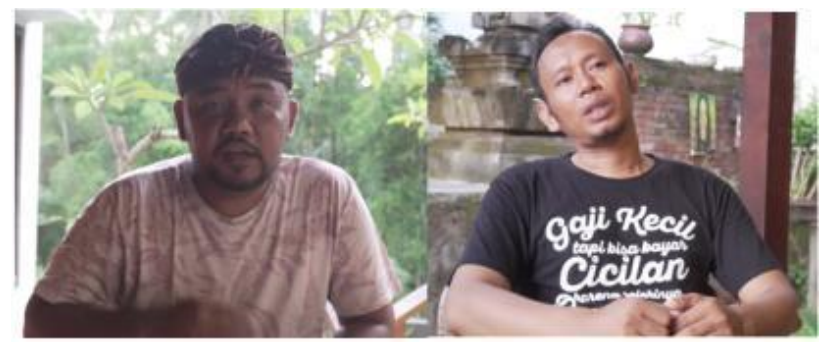

Gambar 6. Pengambilan Gambar Narasumber
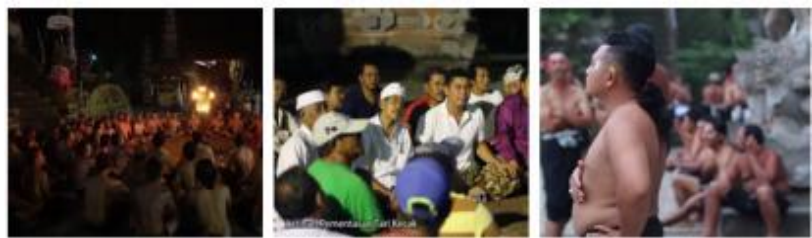

Gambar 7. Pengambilan Gambar Tari Kecak Bedulu

\section{2) Pasca Produksi}

Pada fase pasca produksi dalam pembuatan Film Dokumenter Tari Kecak Bedulu "Terkikisnya Eksistensi Di Tanah Kelahirannya" melalui beberapa tahapan yaitu tahap editing video, editing audio, mixing dan rendering. Adapun hasil dari tahapan tersebut dijabarkan sebagai berikut:

\section{a) Tahap Video Editing}

Proses editing video dalam Film Dokumenter Tari Kecak Bedulu "Terkikisnya Eksistensi Di Tanah Kelahirannya" ini dapat dilihat pada Gambar 5.

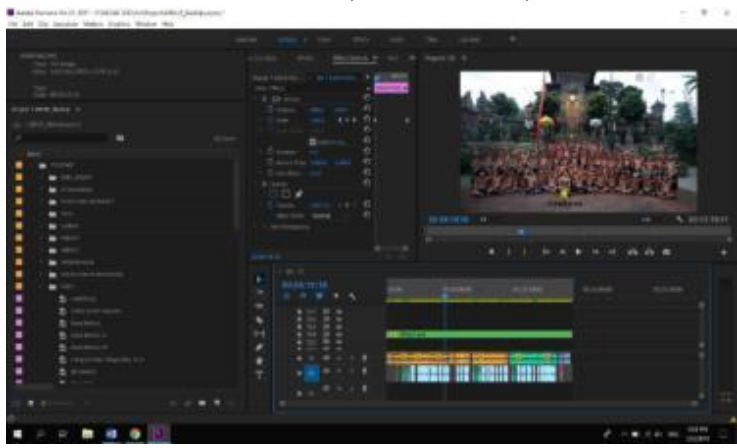

Gambar 8. Proses Editing Video

Dalam tahap editing video ini juga terdapat proses color grading (penyesuaian warna) yang bertujuan menambah/mengurangi ketajaman warna sehingga dapat memberikan kesan cinematic yang menarik Proses color grading dapat dilihat pada Gambar 6

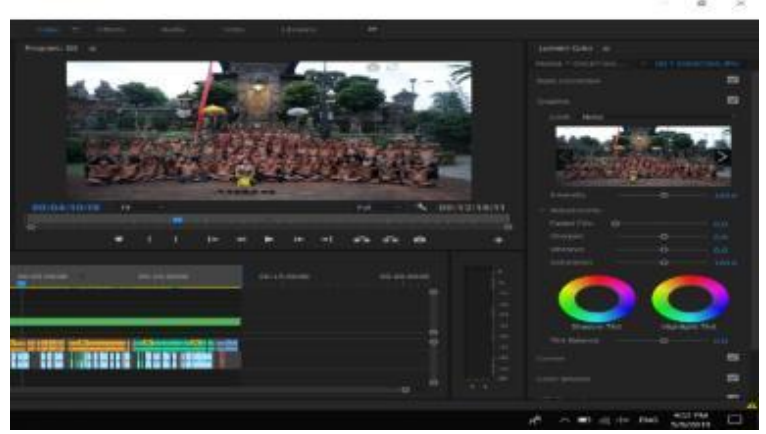

Gambar 9. Proses Color Grading

Selain editing video, yang perlu dilakukan dalam fase pasca produksi ini yaitu tahapan editing audio. Proses editing audio dapat dilihat pada Gambar 7.

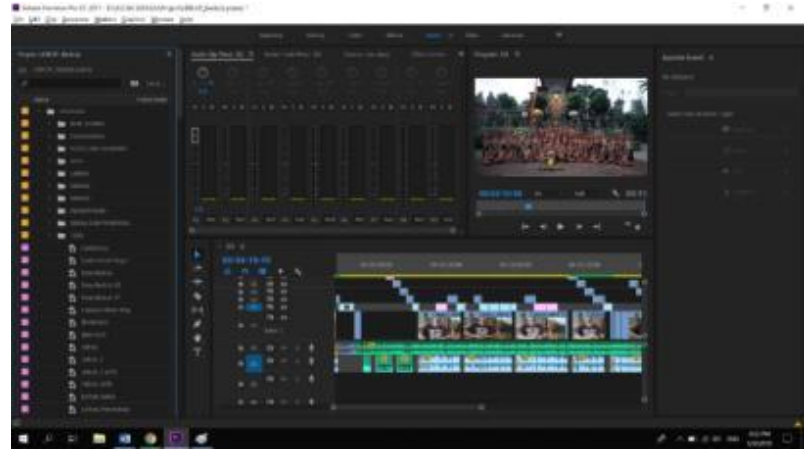

Gambar 7. Proses Editing Audio Mixing

Tahap mixing ini berfungsi untuk menggabungkan video, musik latar, dan effect transisi yang telah diedit sebelumnya. Proses ini dapat dilihat pada Gambar 8 


\section{ISSN \\ Kumpulan Artikel Mahasiswa Pendidikan Teknik Informatika}

\section{KARMAPATI}

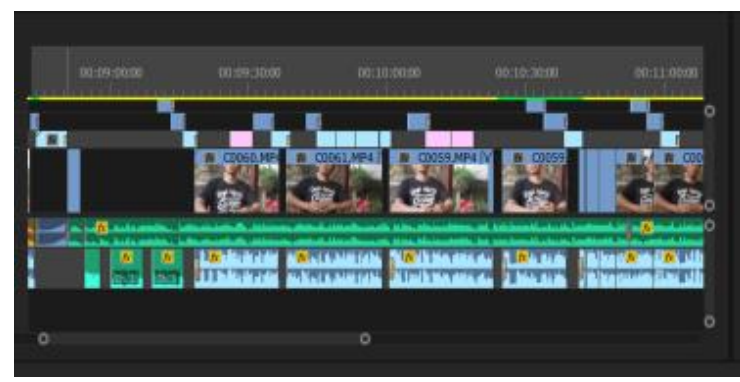

Gambar 10. Proses mixing

\section{b) Rendering}

Proses rendering film dokumenter ini dilakukan setelah proses mixing selesai. Proses rendering pada Adobe Premiere CC 2017 terdapat pada menu fileexport-media. Pada proses rendering, file diubah sesuai format yang telah ditentukan sebelumnya. File yang telah selesai di-render, ditempatkan sesuai dengan direktori tempat meletakkan file tersebut. Proses rendering dapat dilihat pada Gambar 9.

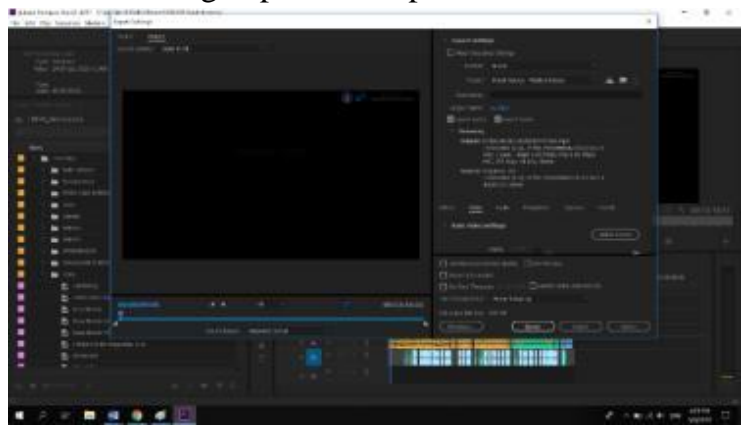

Gambar 11. Proses rendering

\section{Hasil Evaluasi 2}

Tahap Evaluasi yang ke dua ini merupakan tahap pengujian terhadap film dokumenter yang telah dibuat. Pengujian dilakukan terhadap beberapa ahli yaitu :

A. Uji Ahli Isi

Uji ahli isi telah dilakukan dengan cara mencentang jawaban yang menurut para ahli sesuai. Hasil rekapitulasi diketahui bahwa informasi yang terkandung di dalam film dokumenter sudah jelas dan memperoleh persentase sebesar $100 \%$. Nilai tersebut masuk dalam kategori sangat baik berdasarkan persentase yang didapat.

B. Uji Ahli Media

Pengujian ini dilakukan guna mengetahui kelayakan Film Dokumenter Tari Kecak Bedulu
(KARMAPATI)

Volume 8, Nomor 2, Tahun 2019

"Terkikisnya Eksistensi Di Tanah

Kelahirannya"sebagai media informasi kepada masyarakat. Hasil pengujian tersebut dengan perolehan skor keseluruhan 22 dari 22 total skor, maka persentasenya mendapatkan $100 \%$ dan dikonversi kedalam Tabel 3.1 mendapat kulifikasi sangat baik. Jadi proses dapat dilanjutkan ke tahap berikutnya tanpa revisi.

\section{Hasil Tahap 4}

Tahap ini merupakan tahap mastering Film Dokumenter Tari Kecak Bedulu "Terkikisnya Eksistensi Di Tanah Kelahirannya". Di mana pada tahap ini diawali dengan proses burning Film Dokumenter Tari Kecak Bedulu "Terkikisnya Eksistensi Di Tanah Kelahirannya" ke dalam bentuk DVD. Dapat dilihat pada gambar di bawah :

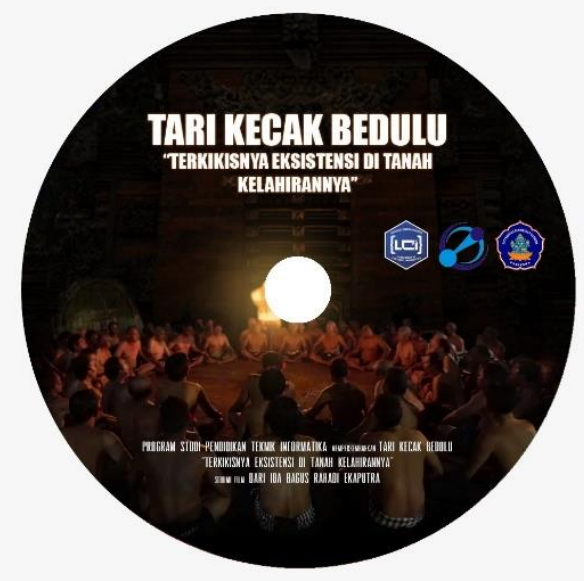

Gambar 12

Keping DVD

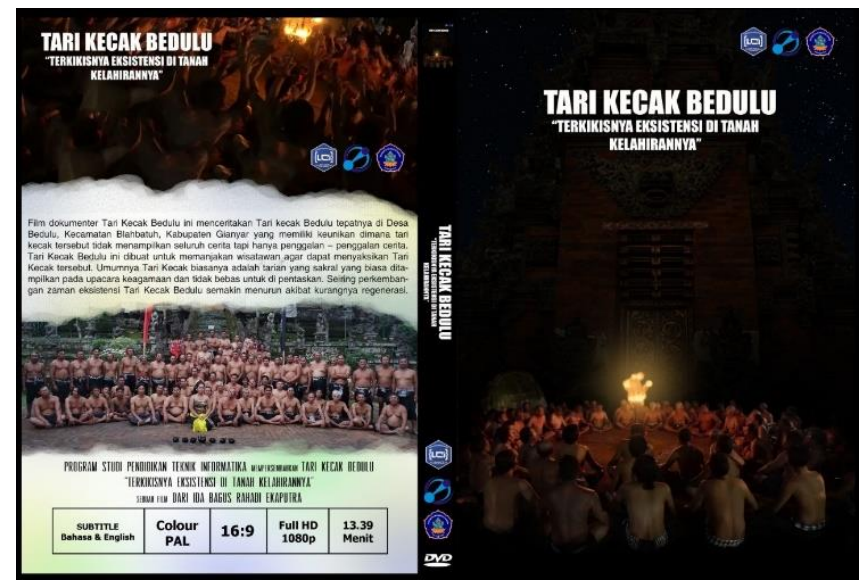

Gambar 13

Sampul DVD 


\section{ISSN \\ Kumpulan Artikel Mahasiswa Pendidikan Teknik Informatika}

\section{Hasil Outcome}

Tahapan terakhir pada pembuatan DVD Film Dokumenter Tari Kecak Bedulu "Terkikisnya Eksistensi Di Tanah Kelahirannya" yaitu tahapan publikasi yang mengunakan media promosi berupa poster dan media sosial. Berikut hasil desain poster dapat dilihat pada Gambar 12

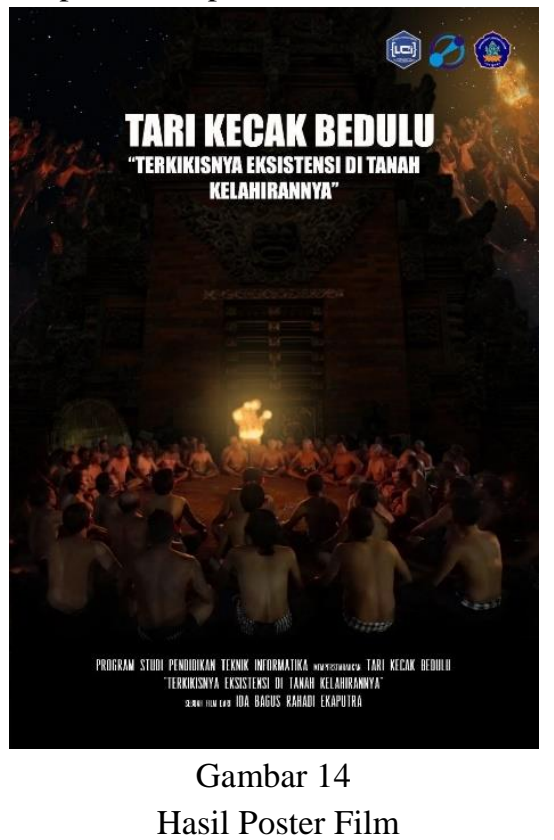

\section{HASIL UJI RESPON PENONTON}

Uji respon penonton adalah pengujian untuk mengetahui bagaimana respon penonton setelah menonton Film Dokumenter Tari Kecak Bedulu "Terkikisnya Eksistensi Di Tanah Kelahirannya". Pada uji respon penonton film dokumenter ini peneliti melakukan pengujian terhadap 30 orang responden yang merupakan masyarakat umum dengan rentangan usia 12 tahun keatas. Hasil dari keseluruhan uji respon penonton diperoleh presentase sebanyak $91,20 \%$ yang dikonversikan ke dalam tabel konversi menyatakan pencapaian baik.

D. PEMBAHASAN

Sesuai dengan pemaparan Film Dokumenter Tari Kecak Bedulu "Terkikisnya Eksistensi Di Tanah Kelahirannya", berikut ini diuraikan Film Dokumenter Tari Kecak Bedulu "Terkikisnya Eksistensi Di Tanah Kelahirannya". Pembahasan difokuskan pada implementasi dan hasil respon penonton Film Dokumenter Tari Kecak Bedulu "Terkikisnya Eksistensi Di Tanah Kelahirannya".

Film Dokumenter Tari Kecak Bedulu "Terkikisnya Eksistensi Di Tanah Kelahirannya" menganut jenis film
Volume 8, Nomor 2, Tahun 2019

dokumenter sejarah dan ilmu pengetahuan, Dalam film ini tipe film dokumenter yang diusung yaitu tipe interactive, di mana nantinya akan ada beberapa tokoh yang memperkenalkan tari kecak bedulu, menyampaikan asal - usul dari tari kecak bedulu, keunikan tari kecak bedulu dan perkembangannya hingga sekarang. Semua bagian tersebut akan ditampilkan lewat wawancara langsung dengan berbagai narasumber seperti, beberapa tokoh Ketua Sekaa Kecak Bedulu dan Seniman Praktisi Tari Kecak Bedulu.

Berdasarkan Film Dokumenter Tari Kecak Bedulu "Terkikisnya Eksistensi Di Tanah Kelahirannya" menggunakan model cyclic strategy. Model cyclic strategy memilki delapan tahapan, antara lain: brief, tahap 1, tahap 2 , evaluasi 1, tahap 3 , evaluasi 2, tahap 4 dan outcome. Pada tahap brief dilakukan menganalisis permasalahan yang ada dan pengajuan ide atau topik kepada ketua Jurusan Pendidikan Teknik Informatika. Setelah ide disetujui akan dilanjutkan ke tahap 1 yaitu melakukan pengumpulan data dan analisis kebutuhan. Pada tahap pengumpulan data, dilakukan pencarian informasi kepada orang-orang yang mengetahui Film Dokumenter Tari Kecak Bedulu "Terkikisnya Eksistensi Di Tanah Kelahirannya". Setelah semua informasi terkumpul, data yang didapat kemudian akan dianalisis. Dalam analisis ini dilakukan analisis talent, analisis lokasi, analisis alat, analisis crew, analisi SWOT dan analisis STP.

Pada tahap 2 dilakukan tahapan pra produksi yang meliputi penentuan ide cerita, sinopsis, skenario dan storyboard. Ide cerita diperoleh dari wawancara terhadap narasumber yang sudah ditentukan. Selanjutnya pembuatan sinopsis yang dibuat berdasarkan ide cerita yang dibuat sebelumnya. Setelah pembuatan ide cerita dilanjutkan dengan pembuatan skenario dan storyboard sebagai acuan dalam proses produksi. Selanjutnya dilakukan evaluasi 1 untuk menguji tahap 1 dan tahap 2.

Tahap 3 adalah tahapan produksi dan pasca produksi Film Dokumenter Tari Kecak Bedulu "Terkikisnya Eksistensi Di Tanah Kelahirannya". Pada tahapan produksi dilakukan proses pengambilan gambar (shooting) di lokasi-lokasi yang telah ditentukan dan pembuatan ilustrasi. Setelah proses pengambilan gambar selesai kemudian dilakukan tahapan pasca produksi film dokumenter. Di mana dalam tahapan ini terdiri dari proses editing film dokumenter, mixing, dan rendering. Setelah pada tahap 3 semua sudah selesai, maka dilakukan evaluasi yang kedua yaitu melakukan uji ahli isi dan uji ahli media. Uji ahli isi dan uji ahli media dilakukan oleh orang-orang yang sudah berkompeten di bidangnya masing-masing. 


\section{ISSN \\ Kumpulan Artikel Mahasiswa Pendidikan Teknik Informatika}

Setelah dilakukannya uji ahli isi terhadap 2 orang, diperoleh hasil pengujian menggunakan angket dengan persentase ratarata penilaian yang diperoleh $100 \%$. Berarti bila dikonversikan ke dalam tabel konversi, berada pada kualifikasi sangat baik. Hal ini berarti isi cerita pada Film Dokumenter Tari Kecak Bedulu "Terkikisnya Eksistensi Di Tanah Kelahirannya" tidak perlu direvisi dan menunjukan bahwa isi informasi di dalam Film Dokumenter Tari Kecak Bedulu "Terkikisnya Eksistensi Di Tanah Kelahirannya" sudah sesuai dan layak untuk dilanjutkan. Namun terdapat saran dari penguji ahli isi 2 yaitu agar bisa disempurnakan sehingga lebih menarik. Sedangkan untuk uji ahli media dilakukan oleh dua orang ahli yang berkompeten di bidangnya. Uji ahli media menggunakan instrumen angket dengan cara mencentang jawaban yang dianggap sesuai, diperoleh hasil rata-rata persentase penilaian yang didapat yaitu sebesar 100\% masuk dalam kategori Sangat Baik. . Namun terdapat saran dari penguji ahli media 1 yaitu pencahyaan perlu duperhatikan mana obyek utama dan shoot angle lebih bervariasi.

Pada tahap 4 dilakukan proses mastering file yang sudah dirender, kemudian dikemas dalam bentuk DVD dan dapat dipublikasikan. Dilanjutkan ke tahap outcome yang merupakan tahap terakhir pada pembuatan Film Dokumenter Tari Kecak Bedulu "Terkikisnya Eksistensi Di Tanah Kelahirannya". Tahapan outcome ini adalah mempublikasian Film Dokumenter Tari Kecak Bedulu "Terkikisnya Eksistensi Di Tanah Kelahirannya" yang telah dibuat dan disosialisasikan dengan media poster.

Uji respon penonton adalah pengujian untuk mengetahui bagaimana respon penonton setelah menonton Film Dokumenter Tari Kecak Bedulu "Terkikisnya Eksistensi Di Tanah Kelahirannya". Pada uji respon penonton film dokumenter ini peneliti melakukan pengujian terhadap 30 orang responden yang merupakan masyarakat umum dengan rentangan usia 12 tahun keatas. Hasil dari keseluruhan uji respon penonton diperoleh presentase sebanyak $91,20 \%$ yang dikonversikan ke dalam tabel konversi menyatakan pencapaian baik.

Pembuatan Film Dokumenter Tari Kecak Bedulu “Terkikisnya Eksistensi Di Tanah Kelahirannya"tidak lepas dari berbagai kendala. Adapun kendala-kendala yang dihadapi salah satunya yaitu menentukkan jadwal untuk shooting wawancara dengan narasumber, di mana beberapa narasumber memiliki kesibukkan yang tidak sedikit sehingga penulis agak kesulitan dalam menentukkan jadwal untuk shooting, namun kendala tersebut dapat teratasi dengan menjalin komunikasi yang baik dengan narasumber sehingga jadwal shooting bisa dikoordinasikan dengan baik.
(KARMAPATI)

Volume 8, Nomor 2, Tahun 2019

Pengambilan gambar, penulis juga mengalami beberapa kendala seperti banyaknya suara noise yang masuk karena kebanyakan pengambilan gambar dilakukan di luar ruangan. Namun dengan memanfaatkan software Adobe Premiere CC 2017 untuk mengurangi noise suara, kendala tersebut dapat diatasi. Selain itu penulis juga mendapatkan kendala dalam hal mengumpulkan crew dalam proses shooting, namun dapat diatasi dengan memaksimalkan peralatan yang ada. Dalam teknik editing video juga terdapat beberapa kendala yaitu kesulitan dalam mengatur resolusi warna video, ini dikarenakan pada saat pengambilan gambar menggunakan kamera berbeda jenis sehingga ketajaman warna yang dihasilkan dari masingmasing kamera tidak sama. Namun kendala tersebut dapat diatasi dengan cara menambahkan effect serta mengatur Brightness \& Contrast pada masing-masing video.

Film dokumenter ini dapat menyampaikan realitas yang ada di lapangan serta dibuat dengan manfaat untuk memberikan wawasan bagi penonton terkait pengenalan Sejarah Tari Kecak Bedulu, Keunikan Tari Kecak Bedulu, serta perkembangannya hingga saat ini. Karena dalam film ini terkandung nilai-nilai filosofis pada Tari Kecak Bedulu untuk masyarakat Bali dan khususnya warga Desa Bedulu agar dapat tersampaikan dengan media yang lebih beragam serta inovatif dan menarik sehingga maryarakat lebih mudah untuk mendapatkan informasi dan membangkitkan minat generasi muda agar ingin melestarikan Tari Kecak Bedulu ini.

\section{SIMPULAN}

Berdasarkan hasil penelitian dan pembahasan Film Dokumenter Tari Kecak Bedulu "Terkikisnya Eksistensi Di Tanah Kelahirannya", maka penulis dapat menarik kesimpulan sebagai berikut.

1. Perancangan Film Dokumenter Tari Kecak Bedulu "Terkikisnya Eksistensi Di Tanah Kelahirannya" telah berhasil dilaksanakan menggunakan model cyclic strategy dengan menggunakan tahapan produksi film yaitu pra produksi (pre production), proses produksi (production), pasca produksi (post production) dan pengujian.

2. Film Dokumenter Tari Kecak Bedulu "Terkikisnya Eksistensi Di Tanah Kelahirannya" sudah berhasil masuk dalam kategori sangat baik sesuai dengan hasil uji ahli isi dan uji ahli media dimana semua penguji menyatakan setiap butir pernyataan sudah sesuai.

3. Berdasarkan analisis terhadap 30 orang responden yang berasal dari masyarakat terutama generasi muda 
dinyatakan bahwa Film Dokumenter Tari Kecak Bedulu "Terkikisnya Eksistensi Di Tanah Kelahirannya"mendapatkan total hasil persentase sebesar $91.20 \%$ yang masuk dalam kategori baik.

\section{REFERENSI}

[1] Suartaya, K. (2016). Cak, Perintis Seni Pertunjukan FaTuritik Bali. Jurnal FSP ISI Denpasar, 1-6.

[2] Effendy, H. (2008). Industri Perfilman Indonesia Sebuah Kajian. Jakarta: Erlangga.

[3] Hayward, S. (2001). Cinema Studies - Key Concept. Edisi 2. London: Taylor \& Francis e-Library.

[4] Sartono, F. S. (2008). Teknk Penyiaran dan Produksi Program Radio, Televisi dan Film. Jilid Ke-2. Jakarta: Direktorat Pembinaan Sekolah Menengah Kejuruan, Direktorat Jenderal Manajemen Pendidikan Dasar dan Menengah, Departemen Pendidikan Nasional.

[5] Sarwono, J., \& Lubis, H. (2007). Metode Riset untuk Desain Komunikasi Visual 1st ed. Yogyakarta: Andy. 